\title{
Postnatal changes in testicular development and androgen receptors immunolocalization in D'Man ram lambs
}

\author{
Nouria Boukenaoui ${ }^{1,2}$, Elara Moudilou ${ }^{3}$, Christine Chevalier, \\ Zaina Amirat ${ }^{1}$, Jean-Marie Exbrayat ${ }^{3}$, Farida Khammar ${ }^{1}$ \\ ${ }^{1}$ Laboratoire de Recherches sur les Zones Arides, Faculté des Sciences Biologiques, \\ USTHB, Algiers, Algeria \\ ${ }^{2}$ Faculté des Sciences Agro-Vétérinaires, Département des sciences vétérinaires, \\ Université Saad Dahlab, Blida, Algeria \\ ${ }^{3}$ Université de Lyon, UMRS 449, Laboratoire de Biologie Générale, Université Catholique de Lyon, \\ Reproduction et Développement Comparés, EPHE, Lyon, France
}

\begin{abstract}
The purpose of this study was to characterize testicular development in D'Man ram lambs, focusing primarily on androgen receptors (ARs) immunolocalization in the adenohypophysis and testis that is not still known in the D'Man ram lamb. Lambs $(\mathrm{n}=12)$ were divided into four groups (three lambs per group). Adenohypophysis and testis were fixed and paraffin-embedded; cross-section $(3 \mu \mathrm{m})$ were stained and evaluated with immunohistochemistry. Testis weight increased at a greater rate between two and five months after birth, which was associated with remarkable changes in testicular histology, including significant increases in the diameter of seminiferous tubules. Spermatogenesis started between three and five months after birth; lumen and elongated spermatids were observed for the first time in three and four months-old animals respectively. ARs detected with immunohistochemistry were located in the nuclei and cytoplasm of adenohypophysis cells, and only in nuclei of testis cells (Leydig, Sertoli, peritubular myoid and germ cells). (Folia Histochemica et Cytobiologica 2012, Vol. 50, No. 1, 38-45)
\end{abstract}

Key words: testis, morphometry, adenohypophysis, androgen receptors immunolocalization, D’Man sheep

\section{Introduction}

Androgens are involved in the development and the physiological function of male accessory sex organs as well as in the functioning of several other organs and tissues [1]. The androgen action is mediated by the androgen receptor (AR) [2], which belongs to the superfamily of ligand-responsive transcription regulators [1-3]. Using immunohistochemistry, ARs have

Correspondence address: J.-M. Exbrayat,

Université de Lyon, UMRS 449,

Laboratoire de Biologie Générale,

Université Catholique de Lyon,

25 rue du Plat, F-69288 Lyon Cedex 02, France;

e-mail: nouria09@yahoo.fr been localized in a variety of tissues, including reproductive tissues in both sexes [4-5].

For a better understanding of the role of androgens in the different reproductive tissues, it is important to define the hormone site(s) action [6]. The localization of androgen receptor within mammalian testicular cells has long been a subject of interest and controversy [7]. More precisely, whether germ cells do or do not contain the androgen receptor remains a matter of controversy [8]. ARs were found only in the somatic cells of the testis (Leydig, Sertoli and peritubular myoid cells) by Fritz [7]. Therefore, production of antibodies against the androgen receptor and their use in immunolocalization studies by several laboratories have led to the hope that this contro- 
versy could be definitively clarified [9-10]. Unfortunately, contradictory results obtained by different researchers [8-11] have kept alive the debate on the location of $A R$ in the testis.

The aim of this study was to determine postnatal changes in testicular development and the distribution of ARs, by immunohistochemistry, in the testes of lambs of D'Man sheep from two to five months after birth to better understand the role of androgens in different tissues involved in the process of reproduction, particularly of sheep.

\section{Material and methods}

The experiment was conducted at El-Meniaa experimental station in Algeria (30³4'N., 02'52'E.). Twelve D'Man ram lambs were used in this study, with three lambs in each of four groups aged from two to five months. All experimental animals were reared in semi-liberty, fed fresh alfalfa, barley, and straw and had free access to water. Body weights, plasma and tissue samples were measured once a month from two to five months of age.

Tissue preparation and processing. After slaughter of the lambs, the pituitary gland and testes were removed. Right and left testis were trimmed of the epididymis, weighed and sectioned perpendicularly to their long-axis, starting from the center samples ( $\sim 3 \mathrm{~mm}$ thick). Immediately after, samples (pituitary gland and testis) were fixed in $10 \%$ formaldehyde in phosphate buffered saline (PBS). After more than $24 \mathrm{~h}$ of fixation, samples were then dehydrated in increasing concentrations of ethanol, cleared in toluene and embedded in paraffin. Sections of paraffin at $3 \mathrm{~mm}$ were stored at room temperature until morphometric analysis and androgen receptor immunohistochemistry.

Histomorphological analysis. Testicular sections were stained with modified azan [12] and adenohypophysis sections were stained with Cleveland and Wolfe's trichrome (Herlant's method); specificity of this staining has been confirmed with immunocytological methods in the sheep and numerous other species [13]. Testis and adenohypophysis sections were observed under a bright field microscope, and digital images were obtained with a digital camera attached to the microscope. The diameter of the seminiferous tubules was measured in 50 tubules in each sample using a computerized program (light microscope Nikon Eclipse E 400 connected to a Nikon DXM 1200 digital camera). The diameter of the tubules was measured only on the circular tubules. The sections were used to evaluate the maturation of the testis.

Androgen receptor immunohistochemistry. Androgen receptor (AR) immunohistochemical studies were performed using the avidin-biotin complex method (ABC), using the Vectastain Elite ABC kit (Vector Laboratories, Burlingame, CA, USA).
Paraffin sections ( $3 \mu \mathrm{m}$ thick) were deparaffinized, hydrated through a graded ethanol series $(100 \%, 95 \%$ and $70 \%)$, and washed in PBS. Immunohistochemistry was performed on deparaffinized conjunction sections with heat-induced antigen retrieval in citrate buffer ( $\mathrm{pH}$ 6.0) using a pressure cooker, as previously described in the prospectus for the kit "Vector Antigen Unmasking Solutions" (Vector Laboratories, CA, H3300).

This was followed by endogenous peroxidase blocking $3 \% \mathrm{H}_{2} \mathrm{O}_{2}$ in PBS for 5 min at room temperature. All washes between antibody or reagent incubations were rinsed $2 \times 5 \mathrm{~min}$ at room temperature in PBS, and all incubations were carried out in a wet chamber. Tissue sections were first submitted to the appropriate serum in order to block non-specific binding sites. After that, sections processed for AR labeling were incubated with normal horse serum at room temperature for $5 \mathrm{~min}$, and then with both avidin and biotin sites subsequently blocked (Vector Laboratories, CA, SP-2001). All sections were incubated overnight at $4{ }^{\circ} \mathrm{C}$ with the primary antibody: a rabbit polyclonal antibody (N20) raised against a peptide within the N-terminal domain of the human AR (sc-816, Santa Cruz Biotechnology, Santa Cruz, CA, USA), which was diluted at 1:200 in PBS. Bound antibodies were visualized by incubating the sections with biotinylated secondary antibody (Vectastain Elite ABC kit-Vector Laboratories, CA, \#PK-6200) for $30 \mathrm{~min}$. Labeling of AR was visualized with 3,3'-diaminobenzidine-tetra-hydrochloride chromogenic substrate (SK-4100, DAB substrate kit for peroxidase; Vector Laboratories) and were monitored microscopically. Sections were counterstained with hematoxylin (Hematoxylin QS, H-3404; Vector Laboratories, Burlingame, CA, USA). These sections were dehydrated and mounted. Images were captured using a microscope (light microscope Nikon Eclipse E 400 connected to a Nikon DXM 1200 digital camera).

Sections incubated with normal horse serum instead of primary antibody were used as negative controls.

Statistical analysis. Body weights, testicular weights and diameter of the seminiferous tubules were expressed as the mean \pm SEM. Data was analyzed using two-factor ANOVA (Systat, Version 12). Correlations analysis was used to determine Pearson correlations among diameter of the seminiferous tubules and testicular weight. Differences with values of $\mathrm{p}<0.05$ were considered to be statistically significant.

\section{Results}

\section{Body weight, testis weight and diameter of the seminiferous tubules}

Age-related changes in body weight, weight of testes, and diameter of the seminiferous tubules is presented in Figure 1. The average body weight in two 

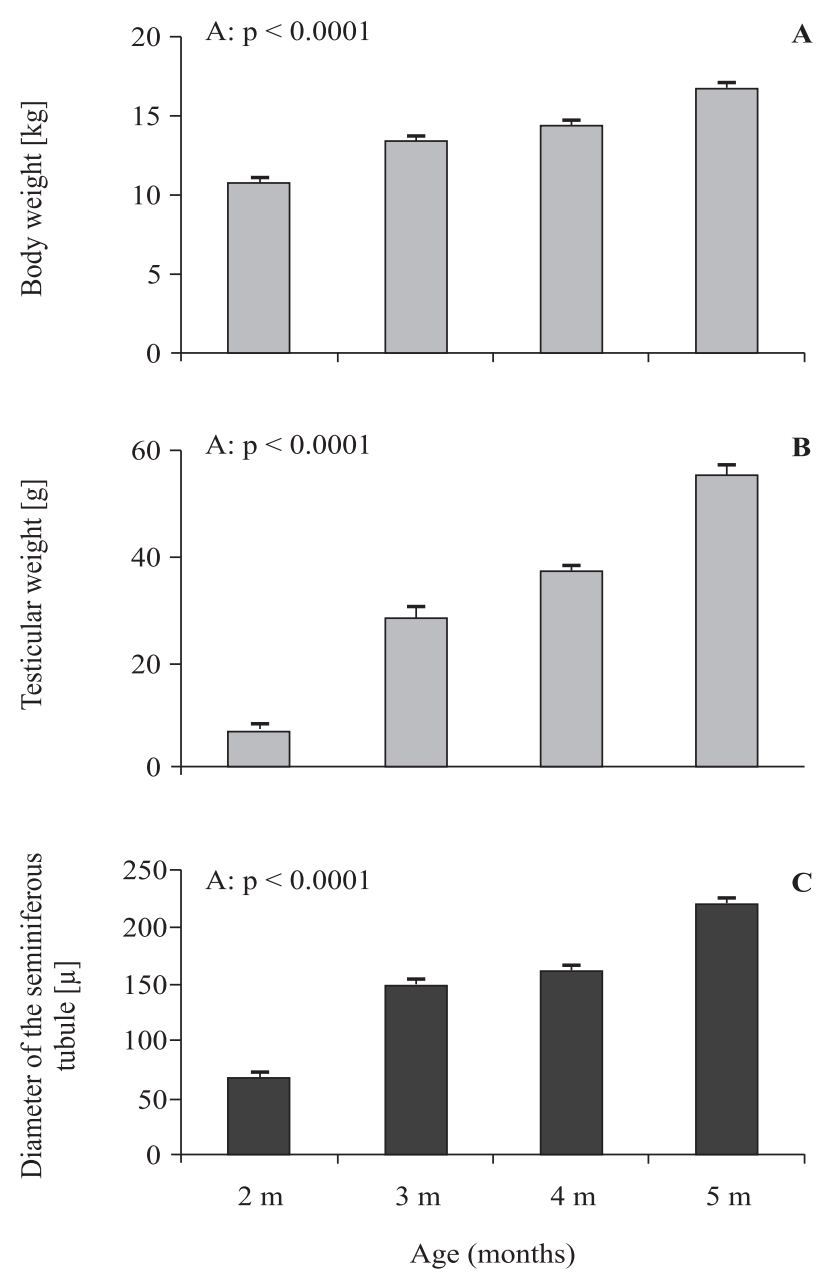

Figure 1. Body weight (A), testis weight (B), and diameter of seminiferous tubules $(\mathbf{C})$ in D'Man ram lambs at different age groups $(n=3)$. Values with different superscripts differ significantly among age groups at $\mathrm{p}<0.05$

months-old animals was $10.7 \pm 0.3 \mathrm{~kg}$, and increased by about $24.3 \%$ by three months $(13.3 \pm 0.3 \mathrm{~kg})$; between three and five months, body weight increased 1.3 -fold (Figure 1A). The average testis weight in two months-old animals was $7.3 \pm 0.4 \mathrm{~g}$, and increased significantly $(\mathrm{p}<0.0001)$ (Figure $1 \mathrm{~B})$ from two months $(7.3 \pm 0.6 \mathrm{~g})$ until five months $(54.8 \pm 3.0 \mathrm{~g})$; the largest growth rate (7.5-fold) was observed between two and five months after birth. The testicular growth was particularly accelerated (3.9-fold) between two and three months after birth.

During the period of study between two and five months after birth, testes grew at a relatively larger rate than body weight; testis weight increased 7.5 -fold and body weight increased only 1.7 -fold. There was a gradual and linear increase in body weight and testicular weight from two to five months after birth (Figures 1A, B). The smallest diameter of seminiferous tubules $(68.3 \pm 6.8 \mu \mathrm{m})$ was observed in the two months-old animals, and this diameter increased lin- early and significantly ( $\mathrm{p}<0.0001)$, reaching a maximum in the five months-old animals $(218.8 \pm 2.1 \mu \mathrm{m})$ (Figure 1C). There were two important periods of growth: a first increase (117\%) was observed between two and three months after birth, and a second increase $(47 \%)$ was observed between three and five months. The diameter of the seminiferous tubules was highly correlated with testicular weight $(r=0.99)$.

\section{Histology of the adenohypophysis}

The tissue of the adenohypophysis is composed of winding cords of epithelial cells flanked by vascular sinusoids. In sections stained with Cleveland and Wolfe's trichrome, as in other vertebrates, three distinct cell types were seen among epithelial cells. Acidophilic cells corresponding to lactotropic or somatotropic cells have cytoplasm that stains red or orange. Basophilic cells corresponding to gonadodroph cells have a bluish cytoplasm. Chromophobic cells have a very poorly stained cytoplasm, and they correspond to both degranulated somatotropic cells and corticotropic cells [13] (Figure 2A).

\section{Histology of the testis}

In the two months-old animals, testes were well developed with a very compact interstitial tissue (Figure 3A). The seminiferous tubules contained Sertoli cells, gonocytes not yet attached to the peritubular walls, and early spermatogonia adjacent to tubule walls. All seminiferous tubules were observed such as solid cord, without any central lumen (Figure 3A). The seminiferous tubules appeared limited with basal lamina and peritubular myoid cells. The basal lamina was very thick and surrounded the cell types present at this period of life, i.e. immature Sertoli cells and gonocytes. Intertubular tissue was observed between the seminiferous tubules. Leydig cells were very abundant, being the dominant component of the interstitial tissue. Leydig cells were characterized by a large size, an irregularly shaped nucleus, and a prominent cytoplasm. Gonocytes were the only type of germ cells observed in an immature testis, and they were located in the center of the tubule, surrounded by Sertoli cells (Figure 3A). Sertoli cells were distributed between the spermatogenic cells. Nuclei of Sertoli cells were ovoid or angular, large and lightly stained, and often contained a large nucleolus.

In the three months-old animals, several seminiferous tubules had completed spermatogenesis. Spermatocytes began to appear. Late spermatocytes were present in $80 \%$ of the seminiferous tubules (Figure 3B).

Between three and five months after birth, the interstitial tissue of a testis showed a dramatic reduc- 


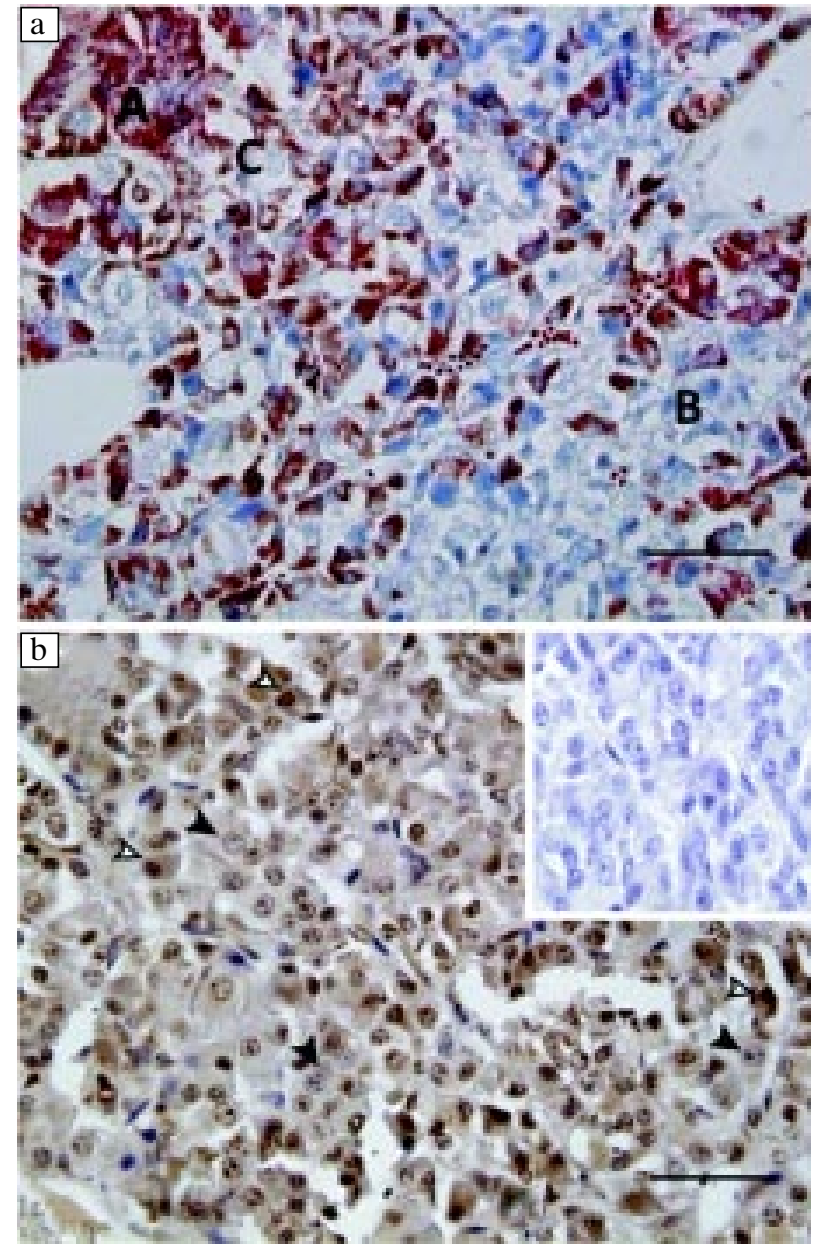

Figure 2. Adenohypophysis sections in D'Man ram lambs. a. Histology, b. Immunohistochemical localization of androgens receptor. A: acidophilic cell; B: basophilic cell; $\mathrm{C}$ : chromophobic cell. Cleveland and Wolfe trichrome staining (a). Immunolabeling in the nuclei cells (empty arrowhead), without immunolabeling in the nuclei cells (full arrowhead) (b). The insert shows the negative control. Scale bar $=50 \mu \mathrm{m}$

tion, with a single or several Leydig cells surrounded by blood vessels (Figures 3B, C). At this period, a distinct central lumen was observed in all the seminiferous tubules (Figures 3B, C). Sertoli cells nuclei varied in shape and in size, but were always located on the periphery of the seminiferous tubule. Some gonocytes migrated to contact the basal lamina, and they differentiated into spermatogonia. Primary spermatocytes larger than spermatogonia appeared. A large number of primary spermatocytes were always visible on sections through seminiferous tubules. Secondary spermatocytes were smaller than the primary spermatocytes. Spermatids were observed in the luminal part of the seminiferous epithelium. They were initially small, with a very light nucleus. Some tubules showed development into longated spermatids or sperma-

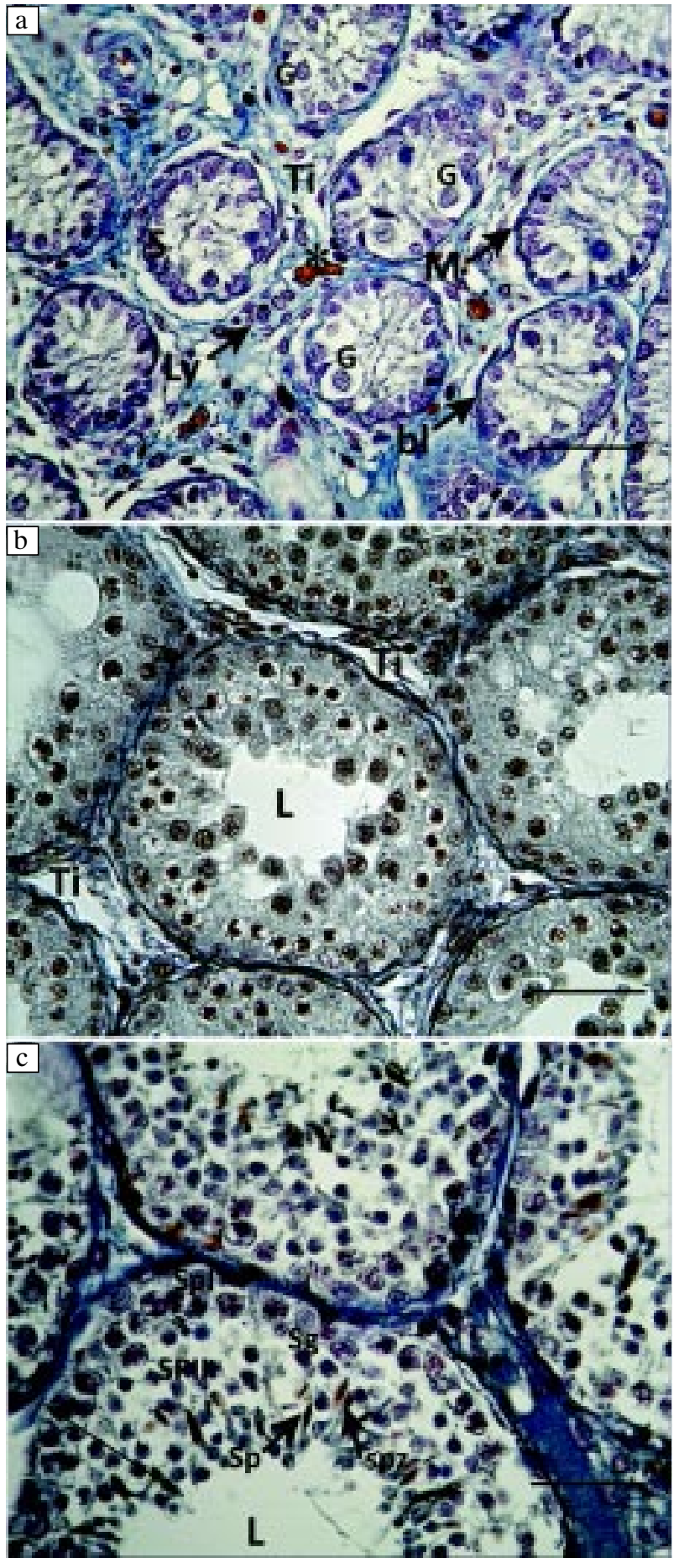

Figure 3. Histology of the testis of D'Man ram lamb at the age of (a) 2 months, (b) 3 months, and (c) 4-5 months.

$\mathrm{Ti}$ - interstitial tissue; Ly — Leydig cells; $\mathrm{M}$ - peritubular myoid cells; S - Sertoli cells; L — lumen; G — germ cells; bl — basal lamina; *blood vessel; SpI — spermatocyte I;

SpII — spermatocyte II; Sg — spermatogonia;

Sp — spermatid; spz — spermatozoa; seminiferous epithelium (black arrow). Azan staining. Scale bar $=50 \mu \mathrm{m}$

tozoa (Figure 3C). In the five months-old animals, each testis was very heterogeneous and all the cell types were present; spermatocytes, and round or 
elongated spermatids were almost equal in quantity (Figure 3C). Full adult spermatogenesis was observed in seminiferous tubules.

\section{Androgens receptor immunolocalization}

After immunostaining of androgen receptor, both adenohypophysis (Figure 2B) and testis (Figure 4) of D'Man lambs showed a positive reaction between the androgen receptor and androgen receptor antibody used.

In the adenohypophysis, immunolocalization with anti-AR showed a nuclear labeling in about $50 \%$ of cells (Figure 2B). Light cytoplasmic and nuclei staining were also consistently observed in some cells.

In testis, labeling is observed in both interstitial compartment and seminiferous epithelium (Figure 4). In the interstitial compartment, specific labeling of AR was found in some Leydig cells with variable staining intensity (Figure 4). In tubular compartment, AR immunoreactivity was localized in the nuclei of Sertoli cells, peritubular myoid cells, and germ cells. In the two months-old animals, immunolabeling for AR was from weak to strong in Sertoli cells, whereas germ cells nuclear immunoexpression of AR was detected in some, but not all. Peritubular myoid and Leydig cells were immunostained with AR in interstitial tissue (Figure 4A).

In the three months-old animals, AR immunolabeling was barely detectable in the Sertoli cells of several animals, and spermatocytes were immunostained for AR (Figure 4B). In the 4-5 months-old animals, spermatogenesis was complete and the positivity for AR was found in the nuclei of Leydig, Sertoli, peritubular myoid and germ (spermatocytes, spermatids and spermatozoa) cells (Figure 4C). The intensity of AR immunolabeling was stage-dependent (Figures 4B, C). A high individual variation was still observed at different ages.

Our results were validated by the presence of the negative control (Figures 2-4); according to SuarezQuian et al. [8], the validity of the results of an immunohistochemical study are based primarily on the quality of controls including both positive and negative controls.

\section{Discussion}

The histological structures of the testes observed in lambs, i.e. germ cells and somatic cells described in our studies, were identical to those reported by different authors $[14,15]$ in the same species.

In the two months-old animals, the absence of lumen in seminiferous tubules and the lowest weight

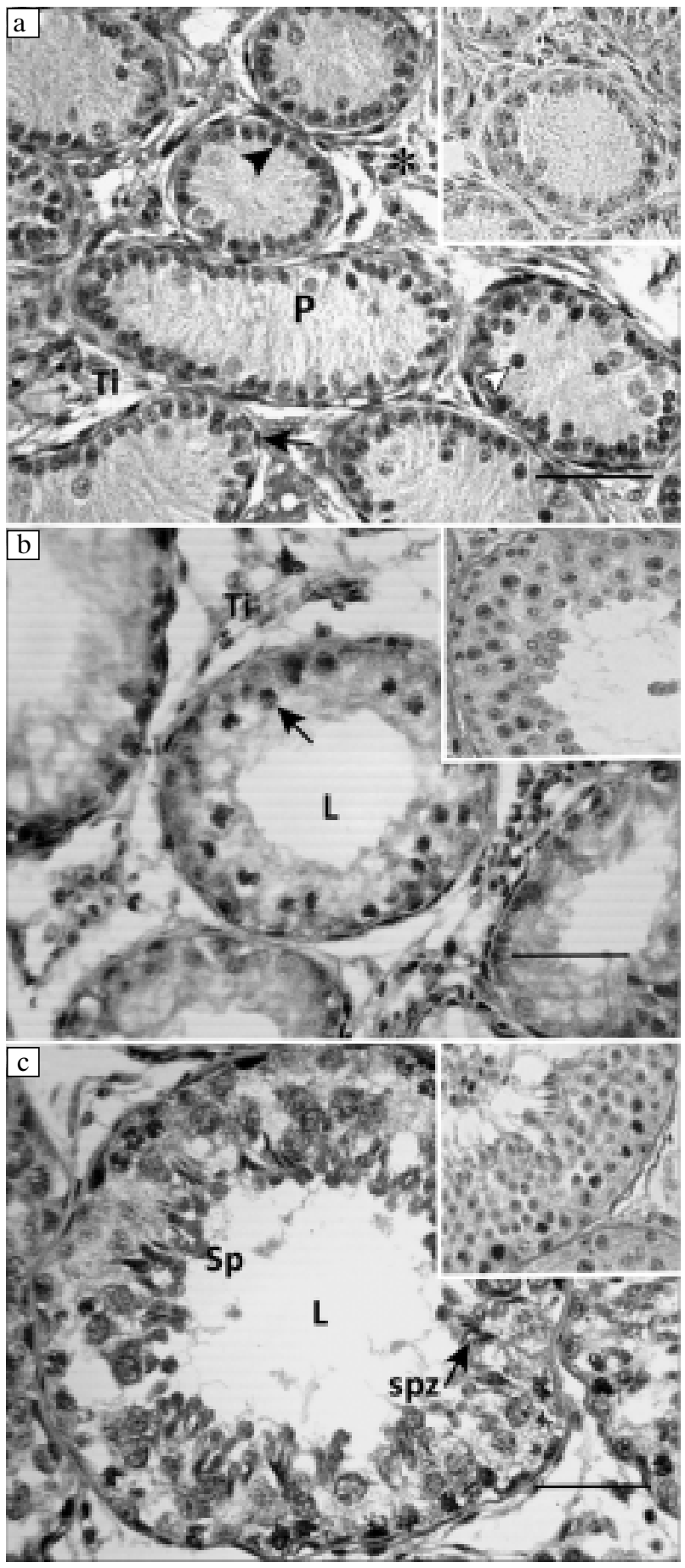

Figure 4. Immunohistochemical localization of androgens receptor in the testis of D'Man ram lambs at the age of (a) 2 months, (b) 3 months, and (c) 4-5 months. In the two months-old animal (a): Sertoli cells (black arrowheads) were immunostained with AR and located at the periphery of seminiferous tubules, whereas germ cells (empty arrowheads) nuclear immunoexpression of AR was detected in some, but not all. Spermatocytes, i.e. pachytene $(\mathrm{P})$ were observed towards the lumen of the tubule. Peritubular myoid (black arrows) and Leydig cells (asterisk) were immunostained with $\mathrm{AR}$ in interstitial tissue (Ti). In the three monthsold animals (b), spermatocytes (black arrows) were immunostained with AR. In the 4-5 months-old animals (c), spermatogenesis was complete. Spermatids (Sp) and spermatozoa $(\mathrm{spz})$ were already being shed into lumen (L). Inserts in (a), (b), and (c) show negative controls. Scale bar $=50 \mu \mathrm{m}$ 
testis indicated the immaturity of the testes [16]. From three months after birth, the appearance of lumen in the center of the seminiferous tubules and the presence of all the cells types of spermatogenesis in the testis, confirmed the onset of puberty [15]. Previously, the occurrence of puberty has been suggested at this age [16]; however, individual variations have also been reported [17]. Growth of the postnatal testis is a consequence of increase in both the tubular and intertubular compartments [18]. It has been [19] explained that the appearance of lumen is a consequence of a high secretion and accumulation of tubular fluid produced by the Sertoli cells. The presence of this lumen demonstrates that the process of development and differentiation of the seminiferous epithelium is functional; also training system junctional-type tight junction between adjacent Sertoli cells is well established [19].

In the pituitary gland, the localization of AR of secretory cells in the anterior lobe is in agreement with a previous report [5] indicating that, in the human pituitary, most of the follicle-stimulating hormone (FSH) and luteinizing hormone ( $\mathrm{LH})$ cells, and some growth hormone $(\mathrm{GH})$ cells, were immunoreactive for AR. In the rat pituitary, AR immunoreactivity was found in the nuclei of some secretory cells which were not identified [9]. These receptors are likely involved in the direct action of androgens on gonadotrophin secretion, as in cultured anterior pituitary cells [20].

Okada et al. [21] reported that the principal feedback action of androgens to decrease LH secretion in male primates, including man, was to slow the GnRH pulse generator, whereas in male rats, androgens not only decreased GnRH, but also suppressed LH synthesis and secretion through a direct pituitary effect. Some studies have provided evidence of differential regulation of secretion by testosterone $(\mathrm{T})$. Testosterone exerts both direct and indirect feedback on LH secretion, whereas its effects on FSH are largely mediated by aromatization to estradiol $\left(\mathrm{E}_{2}\right)$.

From this data, we conclude that, in terms of sex steroid feedback, $E_{2}$ is the predominant regulator of FSH secretion in the human male [22]. Androgens and AR are required for normal spermatogenesis; yet AR expression is not essential in all cell types in the testis [23]. The site of androgens action within the testis, i.e. the cellular distribution of the AR, is not very clear in D'Man sheep. Early studies supported the hypothesis that both germ cells and somatic cells expressed a fraction of the different androgen-binding protein. In contrast, other investigators have been unable to localize AR in germ cells. In adulthood, the action of androgens on seminiferous tubules is essential for full quantitatively normal spermatogenesis and fertility. In a fetal testis, and particularly in fetal germ cell development, androgen's role remains largely unknown [24]. Using testicular feminized (Tfm) mice, Merlet et al. [24] investigated the effects of a lack of functional androgen receptor (AR) on fetal germ cells, and demonstrated that endogenous androgens/AR physiologically control normal gonocyte proliferation. Their data provides in vivo and in vitro evidence of a new control of endogenous androgens on gonocytes identified as direct target cells for androgens.

Nevertheless, when AR was studied by immunohistochemical techniques, conflicting results appeared. In the testes of the D'Man lambs, ARs have been found in the interstitial and tubular compartment. Indeed, Zhou et al. [25] reported that there was a considerable variation, both within and between species, in nuclear steroid receptor localizations in the male reproductive tract. Immunostaining of AR observed in Leydig, Sertoli and peritubular myoid cells was found in mice [8-25], rats [6, 8,9], monkeys [16], primates [26], humans $[9,11,26,27]$, and stallions [28]. Leydig cells are target cells of androgen action in the testis. Indeed, Shan et al. [29] reported that androgens exert a partial inhibitory effect on Leydig cell steroidogenesis. As they synthesize and secrete androgens (particularly testosterone) and contain AR, Pelletier et al. [6] suggested that androgens exerted a paracrine or intracrine regulation by the presence of these receptors. Androgens act to stimulate spermatogenesis through receptors (ARs) on the Sertoli cells and peritubular myoid cells [30]. The presence of AR in Sertoli cells can be related to the role of androgens in the regulation of proteins such as androgen binding protein, which are secreted by the Sertoli cells [31].

Since Leydig cells, which produce testosterone, also contain ARs, it might be suggested that, in this cell type, androgens exert an intracrine or paracrine activity [6]. Myoid cells have been shown to be contractile, involved in the transport of spermatozoa and testicular fluid in the tubule. Furthermore, it has been reported that myoid cells contain androgen receptors and were involved in retinol processing. Considering all that, it is evident that peritubular myoid cells not only provide structural integrity to the tubule, but also take part in the regulation of spermatogenesis and the testicular function. However, their precise roles remain to be resolved [31]. Some authors [8, 16, 27] have reported similar results regarding the presence of labeling in the cells of the germline. In contrast, others $[6,9,11,25,32]$ did not observe labeling at the level of germ cells. In somatic and germ cells of the testis, the presence of androgen receptors (AR) has been demonstrated with variable immunohistochemical positivity according to the age of animal, and the state of the spermatogenesis cycle. The androgens 
mediate a wide range of physiological responses and are especially important in male sexual maturation, the maintenance of spermatogenesis, and male gonadotrophin regulation [33-35]. Verhoeven et al. [35] indicated that the last four steps in germ cell development display clear-cut control by androgen action: spermatid adhesion and development, spermiation, progression through meiosis, and spermatogonial differentiation. For the first three steps, there is an obvious relationship to stages VII and VIII of the cycle of spermatogenesis.

To conclude, in D'Man lambs, the parameters of testicular development increase quickly and linearly during the postnatal period. AR immunoreactivity is found in some cells of the adenohypophysis. The immunostaining of the AR testis is localized at somatic (Sertoli, Leydig and peritubular myoid cells) and germ cells in D'Man lambs.

\section{Acknowledgements}

We would like to thank H. Hadjadj and B. Hakoum for their assistance in this work at the Research Laboratory on Arid Zones (LRZA) in El-Menia station. The immunohistochemical part of this study was supported by the Accord program Algéro-Français 09 MDU 756 CMEP. Thanks to Ms. M.T. Laurent for her kindly assistance.

\section{References}

1. Carson-Jurica MA, Schrader WT, O'Malley BW. Steroid receptor family: structure and functions. Endocr Rev. 1990;11:201-220.

2. Miyamoto J, Matsumoto T, Shiina $\mathrm{H}$ et al. The pituitary function of androgen receptor constitutes a glucocorticoid production circuit. Mol Cell Biol. 2007;27:4807-4814.

3. Evans RM. The steroid and thyroid hormone receptor superfamily. Science. 1988;240:889-895.

4. Ruizeveld de Winter JA, Trapman J, Vermey M, Mulder E, Zegers ND, van der Kwast TH. Androgen receptor expression in human tissues: an immunohistochemical study. J Histochem Cytochem. 1991;39:927-936.

5. Kimura N, Mizokami A, Oonuma T, Sasano H, Nagura H. Immunocytochemical localization of androgen receptor with polyclonal antibody in paraffin-embedded human tissues. J Histochem Cytochem. 1993;41:671-678.

6. Pelletier G, Labrie C, Labrie F. Localization of oestrogen receptor $\alpha$, oestrogen receptor $\beta$ and androgen receptors in the rat reproductive organs. J Endocr. 2000;165:359-370.

7. Fritz I. Sites of action of androgens and follicle stimulating hormone on cells of the seminiferous tubules. In: Biochemical Actions of Hormones. Litwack Edit., Academic Press, New York. 1978;249-281.

8. Suarez-Quian CA, Oke BO, Vornberger W. Localisation du récepteur des androgčnes dans le testicule. Andrology. 1997; 7:293-304.

9. Sar M, Luban DB, French FS, Wilson EM. Immunohistochemical localization of the androgen receptor in rat and human tissues. Endocrinology. 1990;127:3180-3186.
10. Bremner WJ, Millar MR, Sharpe RM, Saunders PT. Immunohistochemical localization of androgen receptors in the rat testis: evidence for stage-dependent expression and regulation by androgens. Endocrinology. 1994;135:1227-1234.

11. Regadera J, Martínez-García F, González-Peramato P, Serrano A, Nistal M, Suárez-Quian C. Androgen receptor expression in Sertoli cells as a function of seminiferous tubule maturation in the human cryptorchid testis. J Clin Endocrinol Metab. 2001;86:413-421.

12. Exbrayat JM. 2001 Genome visualization by classic methods in light microscopy, CRC Press, Boca Raton, London, New York, Washington, D.C.

13. Girod C. Immunocytochemistry of the vertebrate hypophysis. In: Graumann W, Neumann K (eds). Handbuch der Histochemie, vol. 8, supplt, part 5, Gustav Fisher Verlag, Stuttgart New York, 536pp;1983.

14. Courot M. Développement du testicule chez l'agneau. Etablissement de la spermatogénèse. Ann Biol anim Biochim Biophys. 1962;2:25-42.

15. Herrera-Alarcóna J, Villagómez-Amezcuab E, González-Padillac E, Jiménez-Severiano H. Stereological study of postnatal testicular development in Blackbelly sheep. Theriogenology. 2007;68:582-591.

16. Ramesh KC, Craig ML, Joachim W, Ching-Hei Y, Eberhard N, Manuela S. Changes in endocrine profile and reproductive organs during puberty in the male marmoset monkey (Callithrix jacchus). Reproduction. 2006;132:355-363.

17. Boukenaoui N, Amirat Z, Khammar F. Evolution des activités corticosurrénalienne et gonadique, au cours de la croissance pubertaire, chez le mouton D'Man. Sur quelques aspects de la Chronobiologie Eds Bernard BUISSON et Alain BLANC. Publications de l'Université de Saint Etienne Jean Monnet. 2004;145-150.

18. Hocherau-de Reviers MT, Perreau C, Pisselet C, Locatelli A, Bosc M. Ontogenesis of somatic and germ cells in sheep fetal testis. J Reprod Fert. 1995;103:41-46.

19. Russell LD, Bartke A, Goh JC. Postnatal development of the Sertoli cell barrier, tubular lumen, and cytoskeleton of Sertoli and myoid cells in the rat, and their relationship to tubular fluid secretion and flow. Am J Anat. 1989;184: 179-189 .

20. Labrie F, Giguère V, Raymond V et al. Anterior pituitary cells in culture: a precise assay system for hypothalamic and peripheral hormones. In: Advances in Cellular Neurobiology. Eds Federoff S, Hertz L. New York: Academic Press. 1983;381-406.

21. Okada Y, Fujii Y, Moore J, Winters SJ. Androgen receptors in gonadotrophs in pituitary cultures from adult male monkeys and rats. Endocrinology. 2003;144:267-273.

22. Hayes FJ, DeCruz S, Seminara SB, Boepple PA, Crowley WF Jr. Differential regulation of gonadotropin secretion by testosterone in the human male: absence of a negative feedback effect of testosterone on follicle-stimulating hormone secretion. J Clin Endocrinol Metab. 2001;86:53-58.

23. Collins LL, Lee HJ, Chen YT et al. The androgen receptor in spermatogenesis. Cytogenet Genome Res. 2003;103:299-301.

24. Merlet J, Racine C, Moreau E, Moreno SG, Habert R. Male fetal germ cells are targets for androgens that physiologically inhibit their proliferation. PNAS. 2007;104:3615-3620.

25. Zhou Q, Nie R, Prins GS, Saunders PTK, Katzenellenbogen BS, Hess RA. Localization of androgen and estrogen receptors in adult male mouse reproductive tract. J Androl. 2002;23:870-881.

26. Pelletier G. Localization of androgen and estrogen receptors in rat and primate tissues. Histol Histopathol. 2000;15:1261-1270. 
27. Berensztein EB, Baquedano MS, Gonzalez CR et al. Expression of aromatase, estrogen receptor alpha and beta, androgen receptor, and cytochrome P-450scc in the human early prepubertal testis. Pediatr Res, 2006;60:740-744.

28. Pearl CA, Mason H, Roser JF. Immunolocalization of estrogen receptor alpha, estrogen receptor beta and androgen receptor in the pre-, peri- and post-pubertal stallion testis. Anim Reprod Sci. 2011;Article in press.

29. Shan LX, Bardin CW, Hardy MP. Immunohistochemical analysis of androgen effects on androgen receptor expression in developing Leydig and Sertoli cells. Endocrinology. 1997;138:1259-1266.

30. O'Shaughnessy PJ, Verhoeven G, De Gendt K, Monteiro A, Abel MH. Direct action through the Sertoli cells is essential for androgen stimulation of spermatogenesis. Endocrinology. 2010;151:2343-2348.
31. Wilson RM, Griswold MD. Secreted proteins from rat Sertoli cells. Exp Cell Res. 1979;123:127-135.

32. Maekawa M, Kamimura K, Nagano T. Peritubular myoid cells in the testis: their structure and function. Arch Histol Cytol. 1996;59:1-13.

33. Carreau S, Silandre D, Bourguiba S et al. Estrogens and male reproduction: a new concept. Braz J Med Biol Res. 2007;40:761-768.

34. Carreau S, Wolczynski S, Galeraud-Denis I. Aromatase, oestrogens and human male reproduction. Phil Trans $R$ Soc B. 2010;365:1571-1579.

35. Verhoeven G, Willems A, Denolet E, Swinnen JV, De Gendt K. Androgens and spermatogenesis: lessons from transgenic mouse models. Phil Trans R Soc B. 2010;365: $1537-1556$

Submitted: 14 March, 2011 Accepted after reviews: 18 September, 2011 